Jpn. J. Pharm. Health Care Sci.

ノート 31(4) 313-319 (2005)

\title{
市販直後調査の医療機関向け報告書に関する調査検討
}

\author{
後藤伸之*，萱野勇一郎，渡辺享平，矢野良一, \\ 塚本 仁, 青野浩直, 脇屋義文, 政田幹夫 \\ 福井大学医学部附属病院薬剂部
}

\section{Investigation of Early Post-marketing Phase Vigilance Reports}

\author{
Nobuyuki Goto*, Yuichiro Kayano, Kyohei Watanabe, Ryouichi Yano, Hitoshi Tsukamoto, \\ Hironao Aono, Yoshihumi Wakiya and Mikio Masada \\ Department of Hospital Pharmacy, University of Fukui Hospital
}

$\left[\begin{array}{l}\text { Received October 23, } 2004 \\ \text { Accepted February 5, 2005 }\end{array}\right]$

\begin{abstract}
We investigated the situation of early post-marketing phase vigilance reports prepared by pharmaceutical companies for medical institutions. To do this we collected reports prepared by pharmaceutical companies for this purpose and investigated their contents during the period October 2001 to April, 2003. The number of medicines targeted by our investigation was 51.

We found that most pharmaceutical companies were preparing final reports for medical institutions a few months after the early post-marketing phase vigilance was over. However, reports differed greatly regarding such aspects as contents, items reported and analysis methods and information on important adverse effects was difficult to understand. We thus feel that there is a need to standardize the format of early post-marketing phase vigilance reports to make the information in them more useful.
\end{abstract}

Key words — early post-marketing phase vigilance, standardization adverse drug reaction monitoring, clinical evaluation

\section{目的}

新規医薬品の承認審査は, 非臨床試験および治験の データに基づいて, その有効性, 安全性および品質につ いて評価され，承認が与えられるものであるが，治験段 階の安全性情報では患者数, 併用薬, 合併症, 年齢等に おいて限定されたものとならざるを得ないため, 安全性 情報は十分に蓄積されているとはいえない.一方，一 旦, 医薬品が市販されると治験時と比較して使用患者数 は急激に増加し, 患者の背景や状況も多様化するため, 治験段階では知られていなかった重篤な副作用が発現す る恐れがある。また, 今後, 新医薬品の世界同時開発, 同時発売が進展することが予想される中で, 新規医薬品 の市販直後の安全対策はより一層重要なものとなってく る.

こうした新規医薬品の特性に応じ, 特に市販直後に注 意深い使用を促し，重篤な副作用等が発生した場合の情 報収集体制を強化するため「医薬品の市販後調査の基準
に関する省令 (医薬品 GPMSP)」の改正に併せ,「市販直 後調査」制度が2001年10月より新設され施行されてい る。本調査の目的は，製薬企業が医療機関に対して定期 的に注意喚起することによって安全性情報が未報告のま まとなることを防ぎ，重篤な副作用・感染症の症例を迅 速に把握することにある。すなわち，医薬品の安全性情 報の提供・收集活動を積極的に位置づけ，必要な安全対 策を迅速に講じることを目指している ${ }^{1,2)}$.

そこで施行後約 3 年が経過した市販直後調査の結果が どのように医療現場へ報告されてきたかを調査し，どの ような形で医療現場へフィードバックされるべきかにつ いて検討を行ったので報告する。

\section{方法}

調査対象は，2001年10月から2003年 4 月までに承認・ 発売あるいは効能効果が追加された医薬品のうち市販直 後調査対象となり，市販直後調査が終了した医薬品とし た. 調査方法は, 調査対象医薬品の市販直後調査の医療

* 福井県吉田郡松岡町下合月 $23 ; 23$, Shimoaizuki, Matsuoka-cho, Yoshida-gun, Fukui, 910-1193 Japan 
機関向け最終報告書 (以下，報告書と略す)を収集しその 内容を調査した。

\section{1. 報告書記載内容調査}

市販直後調査の報告書の記載内容について下記の項目 を調査した。

1. 副作用の既知・未知による分類の有無

2. 副作用の重篤・非重篤による分類の有無

3. 発生した重篤な副作用の典型的な症例の記載の有 無

4. 副作用分類の方法について (日本語版 ICH 国際医 薬用語集 MedDRA/J : Medical Dictionary for Regulatory Activities/J)による分類の有無)

5 . 発売から 6 力月間の推定使用患者数, 推定使用量 の記載の有無

6. 集積された副作用についての考察や安全性情報の 記載の有無

\section{2. 市販直後調查の報告書作成までの期間}

市販直後調査終了から報告書作成までに要した期間を 調査した。

\section{3. 市販直後調查期間中の情報収集・提供活動状況調査}

本院採用医薬品に関して，市販直後調查期間中に本院 薬剂部へ情報収集・提供活動に訪れた製薬企業 MRの 訪問回数を集計した。

\section{結果}

調査対象医薬品は, Table 1 に示した51品目であった。 調査対象医薬品の内訳は，新規化合物である新医薬品が 33品目で，新規化合物ではなく適応症の追加および刻形
追加が18品目であった，剂形別にみてみると，内用剂が 20 品目, 注射剂が20品目, 外用剂が11品目であった（Table 2 ).

\section{1. 報告書記載内容調査}

報告書に記載されている副作用が既知であるか未知で あるかが記載されていたのは31品目 (61\%)であり，18品 目 $(35 \%)$ は明示されていなかった。希少疾病医薬品であ るシナジス (適応症：新生児，乳児および幼児における Respiratory Syncytial Virus 感染による重篤な下気道疾患 の発症抑制) と小児へ適応拡大された小児用フルナー ゼ®点鼻液25(グラクソ・スミスクライン)の 2 品目の市 販直後調査では副作用報告がなかったとの調査結果で あった(Fig. 1 (1)).

次に，記載されている副作用が重篤か非重篤かに分類 されていたのは，42品目 $(82 \%)$ あったが，重篤か非重篤 かが明示されていない報告書が 5 品目 (10\%) もあった。 また，報告書には重篤な副作用しか記載していないもの が 2 品目 (4\%)あった(Fig. 1 (2)).

また，医療現場において非常に意義深い情報である重 篤な副作用の典型的な症例報告を最終報告書に揭載して

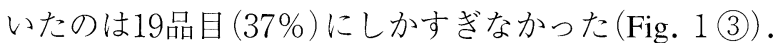

市販直後調査において MedDRA/Jを用いて分類され た報告書は21品目 $(41 \%)$ のみであった Fig. 1 (4))。市販 直後調査期間内の推定使用患者数の記載の有無に関して

Table 2. 調査対象医薬品の内訳

\begin{tabular}{|l|r|r|r|r|}
\hline \multicolumn{1}{|c|}{ 剂形 } & 内用剂 & 外用剂 & 注射剂 & 合計 \\
\hline 新医薬品 & 14 & 4 & 15 & 33 \\
\hline 適応·剂形追加 & 6 & 7 & 5 & 18 \\
\hline 合計 & 20 & 11 & 20 & 51 \\
\hline
\end{tabular}

Table 1. 調查対象医薬品一覧

\begin{tabular}{|c|c|c|c|}
\hline アーチスト錠[追加] & タミフルドライシロップ[追加］ & ダラシンTゲル [追加] & シムレクト注射用 \\
\hline アクトネル錠 & チオラ錠[追加］ & デュロテップパッチ & ゾラデックスLAデポ[追加] \\
\hline アロマシン錠 & プレタール錠[追加］ & フルタイドディスカス[追加］ & 注射用タゴシッド[追加] \\
\hline イレッサ錠 & ベネット錠 & フルナーゼ点鼻液 [追加 $]$ & ノボラピッド注 \\
\hline オキシコンチン錠 & ミカルディスカプセル & ボンアルファハイ軟亳[追加] & パズクロス注・パシル点滴静注液 \\
\hline ガチフロ錠 & レベトールカプセル & アドバフェロン注射液 & ブレビブロック注 \\
\hline カバサール錠[追加] & レルパックス錠 & 注射用エラスポール & ファンガード点滴用 \\
\hline クラリチン錠 & イミグラン点鼻液[追加］ & オフサグリーン静注用 & リゾビスト注 \\
\hline グリベック(CML)カプセル & エイゾプト点眼液 & 注射用オノアクト & リュープリンSR注射用[追加] \\
\hline クリアナール錠·スペリア錠 & エストラダームM[追加］ & オメガシン点滴用 & レミケード点滴静注用[追加］ \\
\hline ジスロマック600mg錠 [追加] & エストラーナ[追加 $]$ & カルセド注射用 & ロイスタチン注[追加］ \\
\hline スオード錠 & キュバールエアゾール & シナジス筋注用 & エクストラニール \\
\hline ストロメクトール錠 & セレベントロタディスク & 注射用シナシッド & \\
\hline
\end{tabular}


(1)副作用の既知・未知の有無

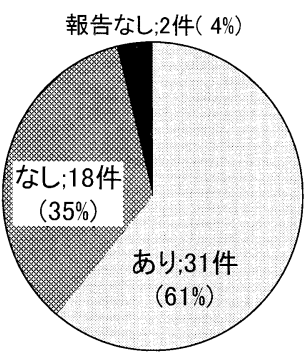

(4) 日本語版ICH国際医薬用語集 MedDRA/Jによる分類の有無

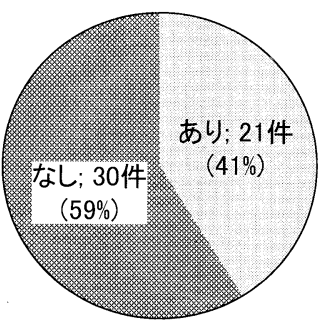

(2)副作用の重篤·非重篤の有無

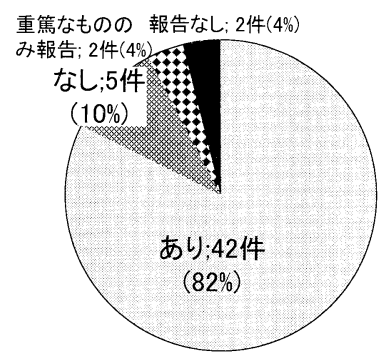

(5)発売から6力月間の推定患者数, 推定使用量の記載の有無

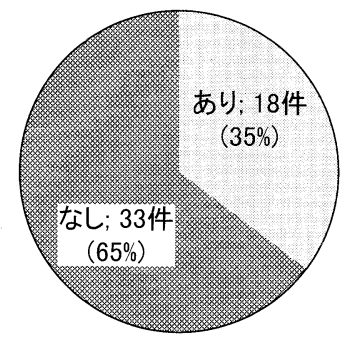

$n=51$

(3)発生した重篤な副作用の典型的

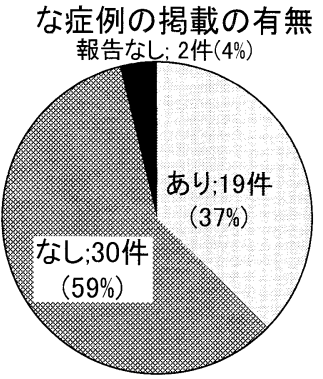

（6)集積された副作用についての考 察や安全性情報の記載の有無

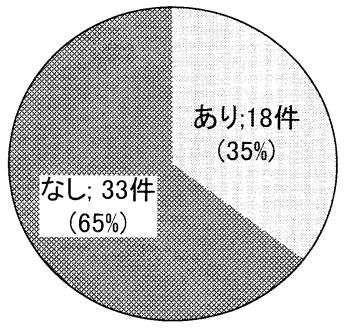

Fig. 1. 市販直後調査の最終報告書記載内容調查結果

は，33品目 (65\%)で推定使用患者数の記載がなかった (Fig. 1 (5)). 33品目 (65\%)が単に集積された副作用の件 数を器官別分類しているだけの報告で, 集積した副作用 についての解析結果や安全性対策についての情報の記載 はなかった(Fig. 1 (6)).

\section{2. 市販直後調查の報告書作成までの期間}

市販直後調査終了後，35品目 (69\%) は 3 力月以内に報 告書を作成していた，不明の 4 件の内訳は，市販直後調 查で副作用報告がなかったり, 報告数が少なく厚生労働 省には報告しているが別途に医療機関向けには報告書を 作成して㧍らず今回のわれわれの調査依頼で初めて報告 書を作成した 3 件と, 当該医薬品の市販直後調查に協力 した医療機関のみに報告した 1 件であった (Fig. 2).

\section{3. 市販直後調査期間中の情報収集 - 提供活動状況調查}

市販直後調查は, 発売直後から 6 力月間が対象とな

り, 製薬企業側は納入から 2 力月以内は概㸚 2 週間に一 度, それ以降は月に一度程度, 副作用収集のための協力 依頼を行いながら調査を行うことになっている，本院採 用医薬品 (26品目)について, 市販直後調查開始から終了 1 カ月後までの間, 本院薬剤部一情報収集・提供活動に 訪れた製薬企業 MRの訪問回数を集計し平均訪問回数 (月間)を求めた結果，各社とも概敉週 1 回以上の訪問頻 度であった(Fig. 3)。しかしながら, 適応追加で市販直 後調查対象になっているにも関わらず調查期間内に一度
も副作用情報収集・提供活動に薬剂部を訪問しない製薬 企業も1社あった。

\section{考察}

市販直後調査で収集された副作用情報を医療機関に フィードバックすることは，適正使用を推進するだけで なく，市販直後調査自体の活性化という観点からも極め て重要なポイントである.インターネットを利用した「市 販直後調査」情報提供システムも試作されているが, 実 稼動には及んでいないのが現状である ${ }^{3)}$ 。そこでわれわ れは，医療機関向けの紙媒体による調查報告書について

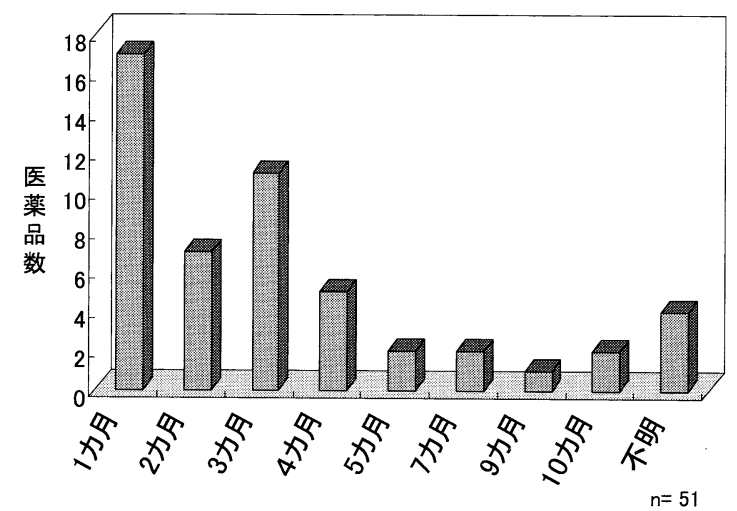

Fig. 2. 市販直後調査終了から医療機関向け最終報告 書ができあがるまでの期間 


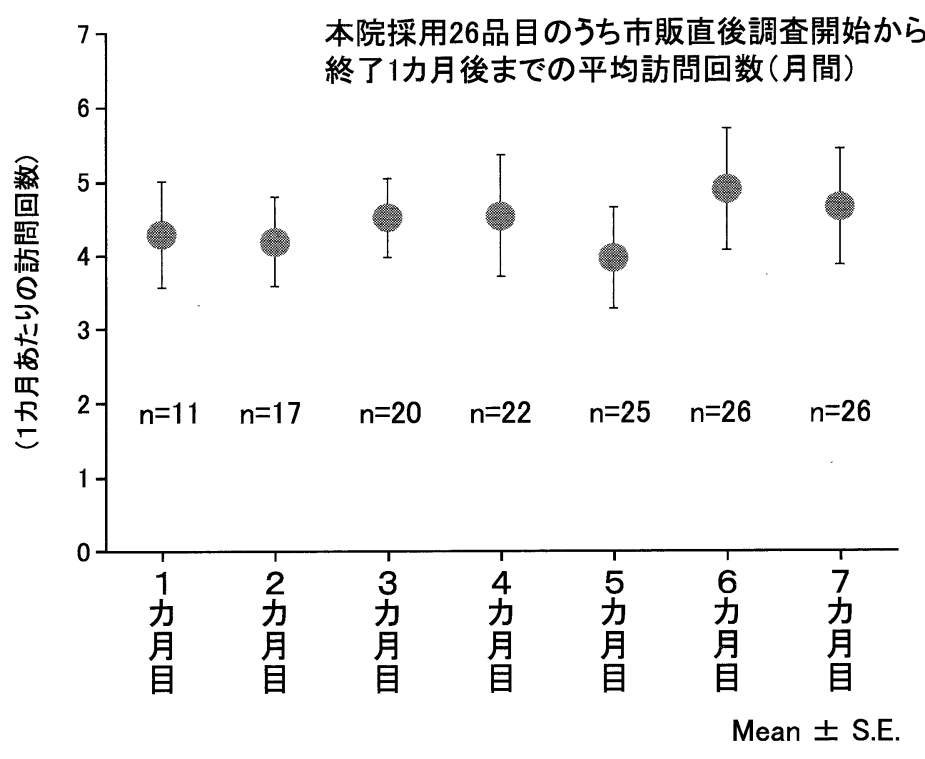

Fig. 3. 市販直後調查中の月間 MR 訪問回数

記載項目や内容を調査した。

今回の検討において, 希少疾病医薬品と小児へ適応拡 大された医薬品で市販直後調査による副作用報告が 1 件 もなかった。市販直後調査の準備段階から希少疾病医薬 品では, 調査期間 6 力月間で症例が集まり市販直後調査 が機能するかどうかが疑問視されていた。また，適応拡 大や効能効果追加についても既存の薬剤とどのように分 離して市販直後調査を実施するかという懸念があり再考 が望まれる。

市販直後調査は，調査期間内のすべての使用患者にお ける重篤な副作用等の発現の有無を網羅的に把握するた めのものと定義されているので，重篤な副作用のみの収 集伝達システムとする傾向があるが，決してその他の副 作用を収集しなくてもよいわけではないことが明言され ている ${ }^{4)}$. 薬事法では，医薬品が市販直後調査の対象の 有無に関らず，製薬企業に対し医薬品の有効性・安全性 に関する事項その他医薬品の適正な使用のために必要な 情報の収集について努力義務規定が設けられており，そ のうち未知で軽微でない症例 (未知中等度症例)について は，その情報を知った日から30日以内に厚生労働大臣に 報告する必要が明記されている。したがって，発生した 副作用が未知か既知かを把握することも重要であり，医 療機関に伝えられるべき情報の1つと考えられる が，35\%の報告書においてこの分類がされておらず各医 療機関で治験時の副作用情報との比較解析に手間を要し ている．さらに，市販直後調査期間内は特に重篤な副作 用に注意を払いながら副作用全般を収集・解析をしなけ ればならないにも関わらず，収集した副作用が重篤か非 重篤かが明示されていない報告書 $(10 \%)$ ，重篤な副作用 しか記載していない報告書 $(4 \%)$ があり，製薬企業間で
も報告内容に対する認識の相違があるものと考えられ る.

発生した重篤な副作用の典型的な症例について は，63\%の報告書に記載がなく，医療現場において意義 深い情報である典型的な症例報告はぜひとも揭載すべき であると考えられる。

また，医療現場においては治験時の安全性情報に市販 直後調査の情報を追加して安全対策を施す必要があるに もかかわらず59\%の報告書で MedDRA/Jによる副作用 分類がされておらず，治験時と市販直後調査の安全性情 報を対比することが難しい状況であった．厚生労働省 は，薬事法に基づく副作用等報告については MedDRA/ J の使用を促進しており ${ }^{5)}$ ，市販直後調査においても MedDRA/Jを使用し器官別大分類した副作用の種類と 発現件数を報告書に揭載すべきであると考える.

市販直後調査期間内の推定使用患者数は，65\%の報告 書にしか記載がみられなかった。販売実績からみた推定 使用患者数は，特に発売当初は在庫分の購入も含まれる ため推定使用患者数が多めに見込まれる懸念があり公開 しない企業も多い.しかし，医療現場としては，正確で ないにしても推定使用患者数が把握出来ずに収集した副 作用数の報告を受けてもその評価や対応に難渋する。市 販直後調査では，一律3,000例の使用成績調査と異なり 調査症例数は求められないが, 厚生労働省医薬食品局安 全対策課に提出する市販直後調査実施報告書には, 調査 対象医療機関の規模と数, さらに推定使用患者数と実施 期間中に講じた適正使用確保措置の記入欄がある。ま た，厚生労働省が緊急安全性情報を報道発表する資料に も販売実績からみた推定使用患者数は含まれてい る. $65 \%$ が単に集積された副作用の件数を器官別分類し 
ているだけの報告書であり，重篤な副作用の再発防止に 向けた安全性対策の内容に関する情報提供は製薬企業の 責務として医療現場に提供すべきである。

市販直後調査は，重篤な副作用等の発現の有無を網羅 的に把握するという有害事象の自発報告強化と医薬品適 正使用の啓蒙という 2 つの側面を持った合理的な制度で ある。しかしながら，市販直後調查は有害事象の自発報 告強化であり，中等度または軽度ではあるが比較的頻度 の高い副作用に関する情報は入手できなくなる可能性が 懸念されるなどいくつかの課題も示されている ${ }^{6,7)}$. 今 後, 業界団体による市販直後調査の方法・報告形式など の標準化の検討が必要であると考えられた。今回の調査
結果を踏まえ, 新医薬品あるいは新効能・効果に対する 安全性情報を的確に医療現場に伝えるための市販直後調 査報告書のモデル案を作成し Fig. 4 に示した. 記載項 目として，まず目次を記し，次に，市販直後調査によっ て得られた結果がどのような使用実態からなっているの かを把握する目的で調査対象の概要 (記載項目：販売名 (一般名), 調査期間, 調査対象施設の数と分類, 推定使 用患者数)を記載する。そして，副作用の収集状況を概 説し，集められた副作用報告について製薬企業なりに 「最も報告の多かった副作用は・・・・」「重篤な副作用 はありませんでした」「添付文書の改訂には至りませんで した」などの考察が必要である。次いで表形式による

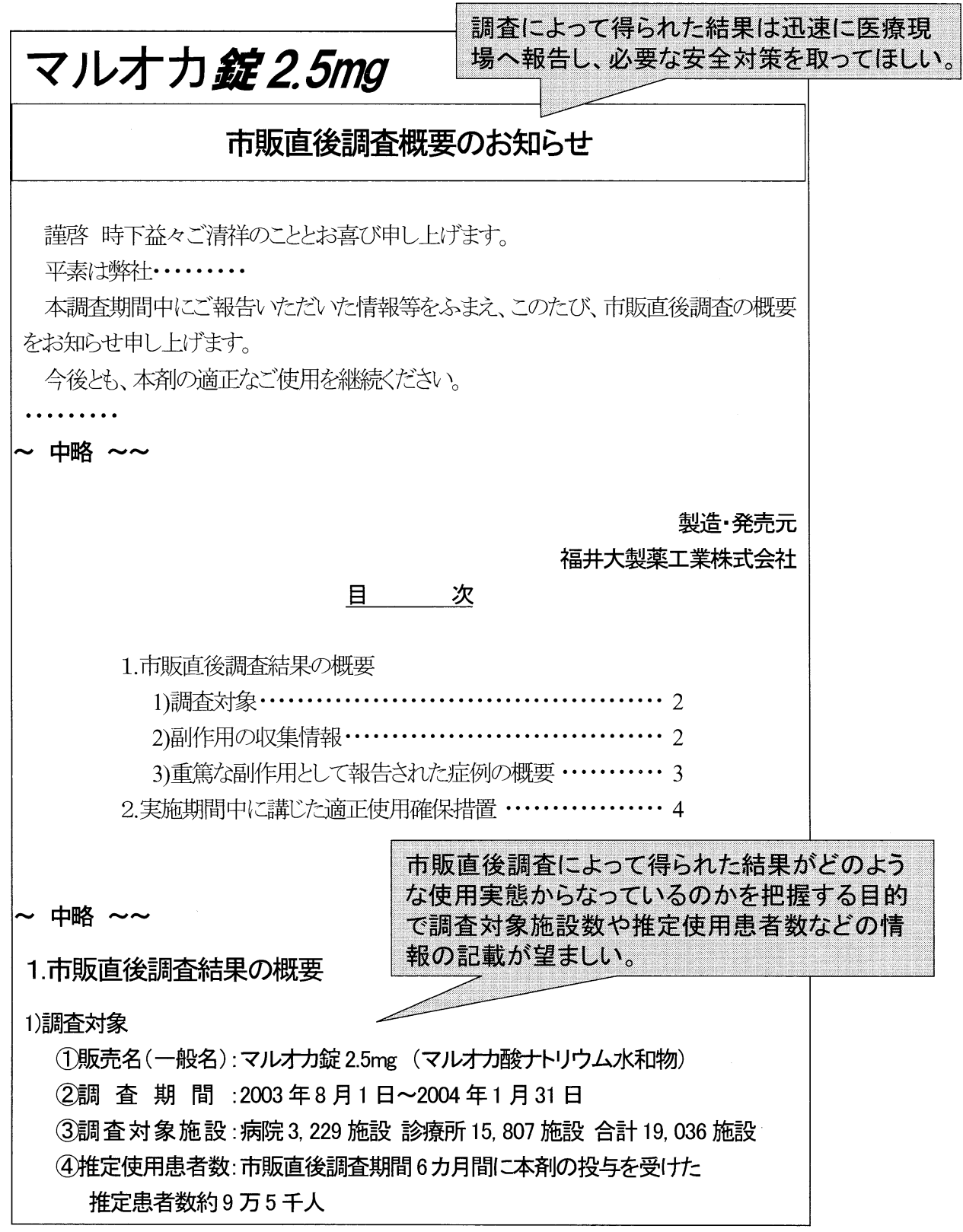

Fig. 4. 市販直後調査最終報告のモデル案 
(Fig.4.つづき)

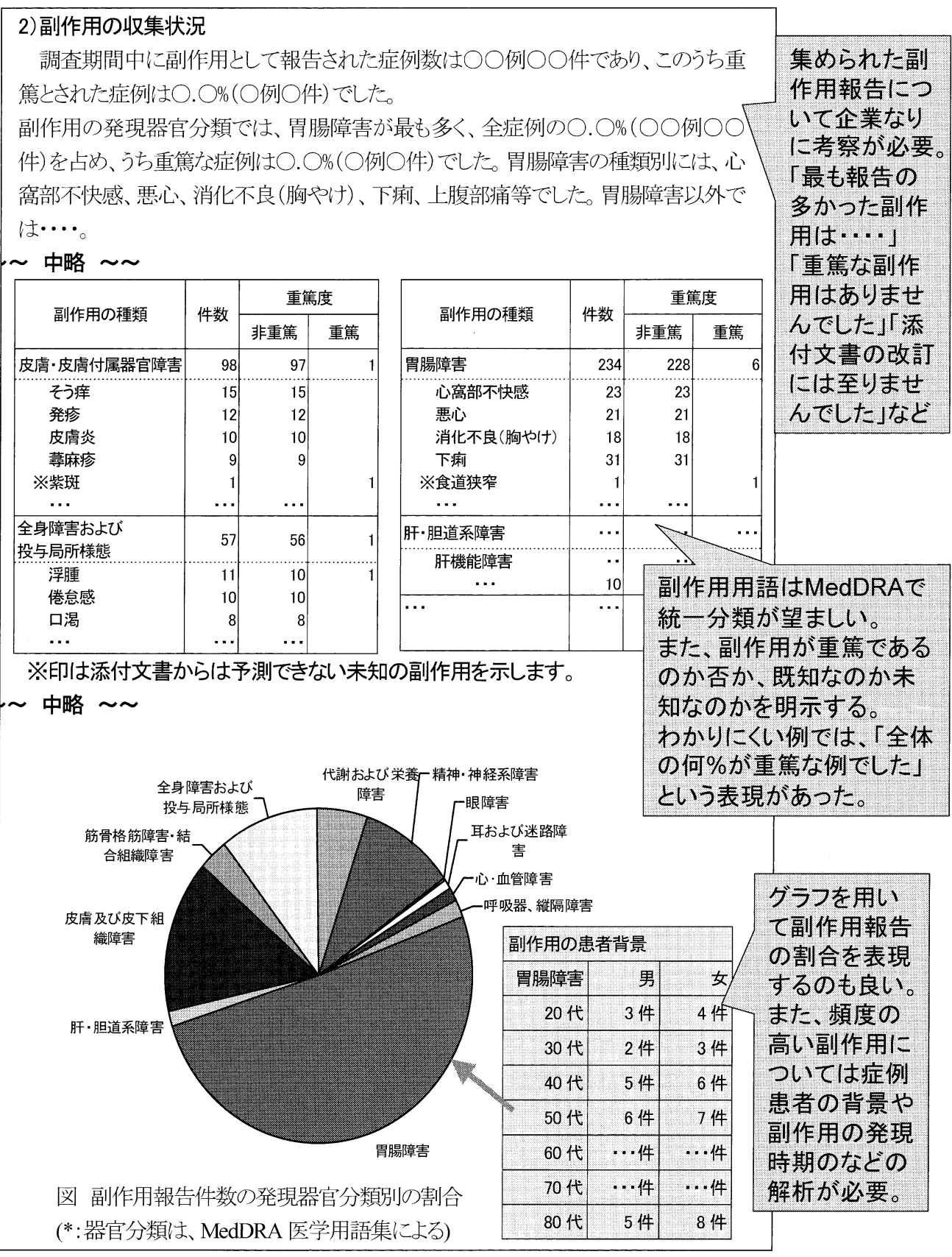

MedDRA/Jで副作用を分類し，各副作用について重篤 であるのか否か，既知なのか未知なのかを明示する。頻 度の高い副作用については症例患者の背景や副作用の発 現時期などの解析や可能な限り層別解析を行い，デー夕 は表型式やグラフ化し分かりやすく表現する。さらに， 重篤な副作用として報告された症例の概要を記載すると 医療現場で非常に役立つ情報源となると考えられる。最 後に，市販直彴調查によって集積された情報をもとに副 作用の初期症状やリスクファクターなど副作用防止のた めの安全性情報など適正使用を確保するための情報を記 載する，以上のような記載項目拉よびフォーマットであ
れば，医療機関は大変活用しやすくなると考えられる。 本院における市販直後調査開始から終了1力月後まで の薬剤部へ情報收集・提供活動に訪れた製薬企業 MR の平均訪問回数(月間)を調査したが，残念ながら今回は 薬剤部への訪問目的が市販直後調査のためか否かまでの 調査は行えなかった。 大学病院という特殊性を配慮する 必要はあるが各社とも概ね週 1 回以上の訪問頻度であっ た。しかし，一部の企業で薬剂部を訪問しない製薬企業 もあり，監視制度の構築も考慮するべきと考えられた。

最後に，充実した市販直後調査を行うために製薬企業 および医療機関の双方が市販後初期の副作用報告に対す 
（Fig.4.つづき）

\begin{tabular}{|c|c|c|c|c|}
\hline \multicolumn{5}{|c|}{$\begin{array}{l}\text { 3)重篤な副作用として報告された症例の概要 } \\
\text { 本剤投与による重篤な副作用として報告された } 11 \text { 例の概要をご紹介いたします。 } \\
\text { この中には、MR が聴取した情報も含まれ、評価材料が不足している症例もありますので、ご留 } \\
\text { 意ください。 } \\
\text { 症 例 } 1 .\end{array}$} \\
\hline \multicolumn{2}{|c|}{\begin{tabular}{|l|} 
患者背景 \\
\end{tabular}} & \multicolumn{2}{|c|}{ 副作用投与開始から発現までの日数及び概要 } & \multirow[b]{2}{*}{ 転帰 } \\
\hline $\begin{array}{l}\text { 性·年齢 } \\
1 \text { 日投与量 } \times \text { 日数 }\end{array}$ & $\begin{array}{l}\text { 疾患 } \\
\text { (既往歷) }\end{array}$ & $\begin{array}{l}\text { 発現迄の } \\
\text { 日数 }\end{array}$ & 概要 & \\
\hline \multirow[t]{2}{*}{$\begin{array}{l}\text { 女· } 50 \text { 歳代 } \\
2.5 \mathrm{mg} \times 15 \text { 日 }\end{array}$} & $\begin{array}{l}\text { 骨粗影症 } \\
\text { 高脂血症 }\end{array}$ & 約 2 週間 & 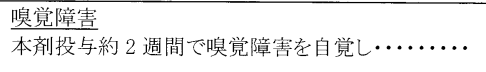 & \multirow[t]{2}{*}{ 軽快 } \\
\hline & \multicolumn{3}{|c|}{ 併用薬: $\bigcirc 0 、 \square \square 、 \triangle \triangle$} & \\
\hline \multicolumn{5}{|l|}{$\begin{array}{l}\text { 症 例 } 2 . \\
\sim \sim \text { 中略 〜 }\end{array}$} \\
\hline \multicolumn{5}{|c|}{ 2. 実施期間中に講じた適正使用確保措置 } \\
\hline
\end{tabular}

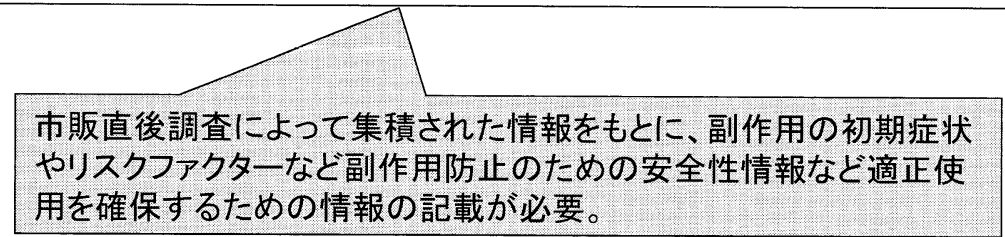

る認識を改め，「市販後に医薬品を育てる」という観点 から今以上に積極的に情報の収集を行い, 得られた情報 を提供し，共有していくことが重要である。そのために も業界団体による標準化された市販直後調査報告が医療 者側にとって有効に利用できる形で迅速に提供されるこ とが不可欠であると考えられる。

\section{引用文献}

1) 倉持憲路，新医薬品の市販直後調査制度について, 日本化学療法学会䧱誌，50, 105-107 (2002).

2) 厚生労働省医薬局: 新医薬品の市販直後調査制度に ついて，医薬品・医療用具等安全性情報 No.170 (2001年9月).
3) 井上学, 吉澤潤治, 「市販直後調査」で収集したデー 夕の情報提供システムの検討, 医療情報学, 22, 307313 (2002).

4) 厚生省医薬安全局安全対策課・審査管理課：「医薬 品の市販後安全対策の改善について(案)」に対する 意見・情報の募集結果について，2000年12月27日．

5) 厚生労働省:「ICH 国際医薬用語集日本語版 (Med$\mathrm{DRA} / \mathrm{J}) 」$ の使用について, 薬食安発第0325001号, 薬食審査発第0325032号，2004年3月25日.

6) 古川裕之，金谷圭子，山崎威志，高木敏治，増江俊 子, 石崎純子, 木村和子, 宮本謙一, 市販直後調査 の効果的な実施方法, 臨床薬理, 33, 287-294 (2002).

7) 大橋靖雄, 特集/わが国におけるPMS の今後のあり 方, PMS 検討会の 1 年 (経過報告), 薬剂疫学, 8, 1-36 (2003). 